\title{
Yapı Kabuğu Performansının Yenilikçi Bir Tasarım Kapsamında Değerlendirilmesi: Yüzeyden Isıtma Soğutma Sistemli Modüler Hibrid Duvar Örneği - İstanbul
}

\author{
Evaluation of Building Shell Performance in the Scope of an Innovative Design: \\ Modular Hybrid Wall Example with Surface Heating Cooling System - İstanbul
}

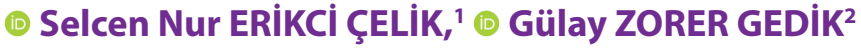

ÖZ

Değişen ve dönüşen dünya ile beraber bina enerji tüketiminin azaltılması enerji korunumu açısından büyük önem taşımaktadır. Bina enerji tüketiminde mekanik sistemlerle harcanan enerji birinci sırada yer almaktadır. Bu nedenle, çalışmada mekanik sistemlerden sonra enerji tüketiminde önemli bir rol üstlenen yapı elemanı olan duvarın farklı bir sistemle düzenlenmesi önerilmektedir. Bu sayede yapı elemanı ve mekanik sistem değerlendirilmesi bütüncül bir yaklaşımla ele alınacaktır. Düşey bina elemanlarının (duvar) yapı kabuğu performansı yenilikçi bir tasarım örneğini de içeren karşılaştırmalı yeni bir yaklaşımla değerlendirilecektir. Çalışmada radyant hibrid duvar sisteminin İstanbul ili için yapı kabuğu performansını belirlemek ve alternatif kesitlerle karşılaştırarak değerlendirmek amaçlanmaktadır. Bu sayede belirlenecek olan yeni bir yaklaşım ile yapı kabuğu performansının değerlendirilmesi sağlanmaktadır. Performans kriterleri ısı kaybı, ses kaybı ve bina maliyetleri olarak belirlenip, hesaplamalar gerçekleştirilmiştir. Sonuç olarak, radyant hibrid duvar sistemi ile farklı yapı kabuğu kesitleri, seçilen Çok Kriterli Karar Verme Yöntemi (ÇKKV) esas alınarak (TOPSIS) İstanbul ili için karşılaştırılmaktadır. Yapılan hesaplamalar ve yöntemler sonucunda elde edilen sonuçlar için en uygun koşulları sağlayan kesit değerlendirilmesi yapılmaktadır.

Anahtar sözcükler: Enerji korunumu; modüler hazır duvar elemanı; performans kriterleri;radyant hibrid duvar; TOPSIS.

\section{ABSTRACT}

Reducing the amount of building energy consumption with changing and transforming world is very important for energy conservation. Energy consumption by mechanical systems is predominant in building energy consumption. For this reason, it is recommended that the wall element should be arranged with a different system. In this way, the structural element and the mechanical system evaluation will be handled with a holistic approach. Evaluations will be made on an approach to integrate building shell performance of vertical building elements (wall) with an innovative design and system. In this study, it is aimed to determine the structure shell performance of radiant hybrid wall system for istanbul province and to compare with alternative sections. In this way, a new approach will be determined and building shell performance will be evaluated. Performance criteria will be determined as heat loss, sound loss and building costs. As a result, the radiant hybrid wall system and different building shell sections will be compared with TOPSIS, which is the Multi Criteria Decision Making Method (MCDM) method, for Istanbul. For the results obtained from the calculations and methods, a section evaluation will be made which provides the most appropriate conditions.

Keywords: Energy saving; modular ready wall element; performance criteria; radiant hybrid wall, TOPSIS (Technique for Order Preference by Similarity to Ideal Solution).

'Nişantaşı Üniversitesi, Sanat ve Tasarım Fakültesi, İç Mimarlık Bölümü, İstanbul

${ }^{2}$ Yıldız Teknik Üniversitesi Mimarlık Fakültesi, Mimarlık Bölümü, Yapı Bilgisi Anabilim Dalı, İstanbul

Başvuru tarihi: 08 Temmuz 2019 - Kabul tarihi: 22 Kasım 2019

İletişim: Selcen Nur ERIKCi ÇELIK. e-posta: selcen.erikci@gmail.com

๑ 2019 Yıldız Teknik Üniversitesi Mimarlık Fakültesi - ๑ 2019 Yıldız Technical University, Faculty of Architecture 


\section{Giriş}

Dünya üzerinde gerçekleşen değişimler son yıllarda yenilikçi tasarım arayışlarına sebep olmaktadır. Ekolojik krizlerin etkileri hem şehir ölçeğinde hem de kırsal alanlar da oldukça gözle görülür hale gelmektedir. Düzensiz ve hızlı yapılaşma ile bu yapılaşma oranlarındaki inanılmaz artış, mikro ölçekten makro ölçeğe değin tüm yaşam arakesitlerini kökünden etkilemektedir. Bu noktada dikkat edilmesi gereken, bina enerji tüketiminin olabildiğince azaltılarak, daha fazla temiz enerji kaynaklarından yararlanmanın arttrılması olmalıdır. Bu nedenle çalışmada, yapı kabuğuna alternatif ve yenilikçi bir tasarım ile radyant hibrid duvar sistemi ele alınmaktadır. Tasarlanan bu sistemde, yüzeyden ısıtmalı soğutmalı duvar elemanı hem modüler hem de hibrid enerji türüne uygun oluşturulmaktadır. Başlıca yapı kabuğu performans kriterleri açısından geleneksel duvar kesitleri karşılaştırması İstanbul için gerçekleştirilmektedir.

Hızlı inşa süreçlerinin istenmesi beraberinde daha hafif, uygulamada kolay ve modüler yapı elemanlarını gerektirmektedir. Hazır beton duvar elemanların veya daha hafif prefabrike elemanların uygulamada daha fazla kolaylık sağlayacak sistemlerle oluşturulması enerji ve ekonomik açılardan fayda sağlamaktadır.

Literatürdeki çalışmalar incelendiğinde yapı kabuğu performansına yönelik birçok çalışma olduğu görülmektedir. Özellikle yerden, tavandan ısıtma sistemi ve hazır dış duvar elemanı üretimine yönelik çokça araştırma bulunmaktadır. Göçer ve Işık, yapı kabuğunun büyük bir kısmını oluşturan dış duvarların, betonarme prefabrike sistemlerle oluşturulması durumunda problem noktaları enerji tüketim verilerine bağlı olarak, kirletici emisyonlarının değerlendirmesini yapmışlardır. Duvar panellerini mimari parametre (yatay, düşey, yatay+düşey, düz etki), boyut (geniş, orta, dar) ve taşıyıcılık (kendini taşıyan, taşınan, taşıyıcı) açısından gruplandırarak, yıllık kirletici emisyonlarını hesaplamışlardır. En düşük kirletici emisyona sahip duvar tipi, bina taşıyıcı sistem elemanlarının tamamen örtüldüğü, ön konumlu, panellerde ve derzlerde ISı yalıtımının kesintisiz olduğu cephe sistemi olarak ortaya çıkmıştır. Bir diğer çalışmada ele alınan hazır beton duvar elemanları sınıflandırılmış ve ısısal konfor açısından incelenmiştir. İncelemede, ülkemizde üretilen ve uygulanan hazır dış duvar elemanları iç yüzey sıcaklıkları ve yoğuşma kontrolleri TS 825 ısı yalıtım yönetmeliğinde verilen dört derece gün bölgesi Ocak ayı dış hava sıcaklık ortalamalarına göre yapılmıştır. ${ }^{1,2}$

Gür ve Aygün, değişen yapı kabukları için konfor koşullarını belirlemeye yönelik bir tasarım destek sistemi geliştirmeye çalışmıştır. Yapı kabuğu ve yapılarda esneklik özelinde ele alınan çalışmada, kabuğun hava geçirgenliği, ışık geçirgenliği, enerji kazanımı, değişkenlik, kontrol vb.

\footnotetext{
1 Göçer vd., $2007 . \quad 2$ Gedik, 2001
}

kriterler belirlenmiştir. Bu değişkenler, bir tablo üzerinde $0,1,2,3,4$ şeklinde (olumsuzdan olumluya) göreceli olarak sıralanmıştır. Bu sayede tasarımcıya öngörülen bu yöntem ile yapı kabuğundaki değişikliklerin kullanıcı konforunu belirlemesi irdelenmektedir. ${ }^{3}$

Tye-Gingras ve Gosselin, hibrid sistemle Isıtilan tavan ve duvar radyant panellerinin konfor ve enerji tüketim optimizasyonu için CFD analizleri yapmıştr. Analizlerde, pencere kenarındaki kısa tavan paneli önde oluşan soğuk hava etkisini azaltarak konforu sağlamaktadır. ${ }^{4}$

Zhang, yerden havalandırma sistemine sahip soğutma tavanlı odalar için dinamik bir model geliştirmektedir. Sistem termal modelinde, odayı dokuz direnç ve alt kapasiteli olacak şekilde oluşturmuştur. Deneysel ölçümler ve modelleme arasındaki karşılaştırmada, sıcaklık değişimleri farkının $0.5 \mathrm{~K}$ olduğu ortaya konulmuştur. ${ }^{5}$

Gemici, gerçek ölçekli bir test sistemi ile farklı panel yerleşimlerini deneysel olarak standartlara göre incelemiştir. Çalışmada, farklı duvar tipi radyant ısıtma paneli yerleşim konfigürasyonlarına farklı derecelerde sıcak su girişi ile ısıl konforun nasıl etkilendiği gösterilmektedir. $0,1 \mathrm{~m}$ ve 1,7 m'deki ortalama hava sıcaklığı farkları sırasıyla $0,14{ }^{\circ} \mathrm{C}$, $1,11^{\circ} \mathrm{C}$ ve $0,73{ }^{\circ} \mathrm{C}$ olarak bulunmuştur. Paneller, üzerinde cam bulunan dış duvara yerleştirildiği durumda diğer durumlara göre daha iyi performans göstermektedir. ${ }^{6}$

Koca vd., IsItmalı radyant tavan sisteminin ISI transfer özelliklerini deneysel olarak incelemiştir. Konvektif ve ışınımlı ısı transfer hızlarını belirlemede tek bir oda tasarımı için farklı konfigürasyonlar oluşturulmuştur. Bu deney odası sayesinde, tavandan ısıtılmamış çevre yüzeylerine kadar sağlanan Isı akısı değerleri ile birlikte radyasyon, konvektif ve toplam ISı transfer katsayısı değerleri hesaplanmıştır. Ayrıca, 28 farklı deneysel vaka çalışması konvektif, ışınımlı ve toplam ISı akısı dâhil deney odasındaki ölçümler ve ISI çıkışı sonuçları, diğer araştırmacıların teorik modellerini ve deneysel korelasyonlarını doğrulamaları için bir tabloda verilmiştir. ${ }^{7}$

Yapı kabuğu performansını oluşturan etkenlerden bir diğeri de, kesitte yer alan malzemelerdir. Yapı kabuğundaki opak malzemelerin enerji, ekonomi ve çevresel etmenler açısından optimizasyonunda iyi yalıtım oldukça önemlidir. ${ }^{8}$ Yapı kabuğundaki yalıtımın yeri ve kalınlığının hem ISı kazancı hem de ısı kaybı açısından hem orta hem de dış yüzeye uygulanması durumunda, iç ortamın dış sıcaklık dalgalanmalarından etkilenmediği ve konforlu iç ortam sıcaklığının elde edildiği gözlenmiştir. ${ }^{9}$ Bu nedenle yalıtım katmanı kalınlık ve kesitteki yeri oldukça önemlidir.

Yukarıdaki çalışmalardan farklı olarak bu çalışmada, enerji tüketimi açısından 0462.STZ.2013-2 no'lu SAN-TEZ

\footnotetext{
3 Gür vd., 2008. $\quad 4$ Tye-Gingras vd., $2012 . \quad 5$ Zhang vd., 2016.

6 Gemici, 2017. $\quad{ }^{7}$ Koca vd., 2018. $\quad{ }^{8}$ Lollini vd., 2006. ${ }^{9}$ Özel, 2003.
} 
projesinde geliştirilen yeni bir duvar sistemi ve yapı kabuğu performansını değerlendiren yeni bir yaklaşım sunulmaktadır. Geliştirilen radyant hibrid duvar sisteminin yapı kabuğu performansının belirlenmesi ve alternatif kesitlerle İstanbul için karşılaştırarak değerlendirilmesi amaçlanmaktadır. Çalışmanın önemi ise, yüzeyden ısıtma soğutma sistemli modüler hibrid duvar elemanlarının hem enerji, hem malzeme hem de uygulama yönleri ile enerji etkinlik kavramlarını desteklemesidir. Böylece konfor sıcaklığına yakın sıcaklığa sahip yüzeyler oluşturularak kullanıcı ve çevre arasında termal denge oluşumu sağlanabilecektir. Kapsamı sınırlandırılan bu çalışmada, radyant hibrid duvarın da aralarında bulunduğu farklı yapı kabuğu alternatiflerinin

- Is|

- Ses ve

- Maliyet

performans kriterleri hesaplamalarla ortaya konulmaktadır. Bu sonuçlar seçilen Çok Kriterli Karar Verme yöntemi TOPSIS - İdeal Çözüme Benzerlik Yoluyla Sıralama Tercihi Tekniği- ile değerlendirilip, İstanbul için en uygun kesit belirlenmektedir.

Bu çalışmada 0462.STZ.2013-2 kodlu sona eren San-Tez projesinin ön tasarım bilgileriyle oluşturulan duvar kesitleri, örnek kesitler olarak ele alınmıştr. ${ }^{10}$

\section{Radyant Hibrid Sistemin Tanımlanması}

Radyant hibrid sistemin modüler olması ve ısıtma-soğutma, yalıtım ve yapısal problemleri kendi içerisinde çözmesi en büyük avantajları arasında gösterilebilir. Kompakt duvar yapı elemanı, ışınımla ısıtma-soğutmanın bir araya getirilmesiyle ortaya çıkmıştır.

Geleneksel duvar türlerine alternatif bir ürün olarak geliştirilen radyant hibrid duvar sisteminde yalıtım ve yapı detayı çözümünün beraber olduğu ve ısıtma-soğutma sistemini de içeren bütünleşik bir sistem tasarımı gerçekleştirilmiştir. Bu sistem ile binanın enerji ihtiyacının minimum seviyelere çekilmesi amaçlanmaktadır. Enerji korunum ve tüketim parametreleri açısından temiz ve alternatif enerji kaynaklı mekanik sistem önerisi oluşturması önemlidir. Isıl performans sistem içerisindeki radyal borular sayesinde gerçekleştirilirken, duvar kesitine giren yapı malzemeleri ile radyal boruların modüler bir ünite içerisinde birlikte üretimi gerçekleştirilmektedir. Yalıtım ve ısıtma-soğutma sistemlerinin duvar içerisinde beraber çözümünün yapıya katkıları ise;

- Yüksek iş̧̧ilik maliyeti ve zaman kaybının azalması

- Binalarda birim hacim başına olan ağırlığın azaltııması

- Taşıyıcı özelliği olmayan yapı elemanlarının bina statik yüküne olan etkisinin minimum seviyelere indirilmesi

\footnotetext{
${ }^{10}$ Gedik vd., 2016.
}

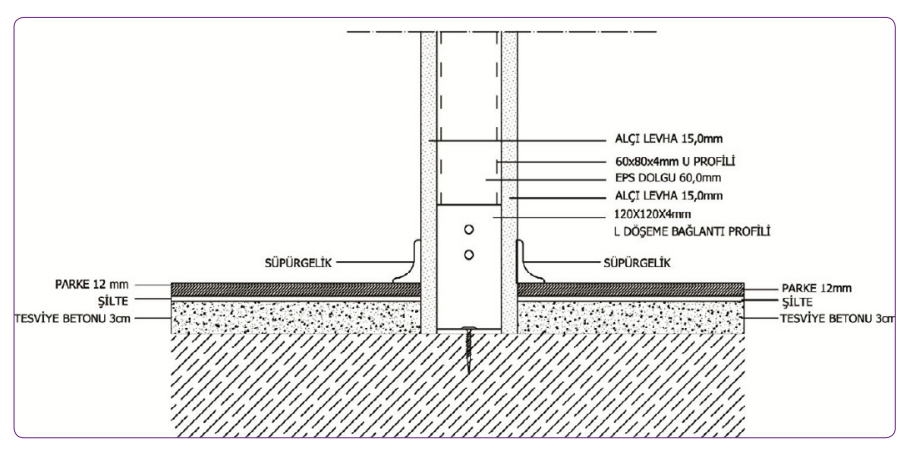

Şekil 1. Tamamlayıcı iç duvar paneli. ${ }^{10}$

- Isıtma döneminde iç yüzeyde ve kesitte yoğuşma sorununa çözüm getirmesi

- Panel içi ve birleşim noktalarında ISI köprülerinin oluşmaması

- Modüler tasarımı sayesinde kullanım kolaylığı

- Işınım yoluyla ısıtma-soğutma sayesinde iç mekân konfor sıcaklık değerlerini homojen olarak sağlayabilmesi olarak sayılabilmektedir. ${ }^{11}$

\section{Yüzeyden Isıtma-Soğutmalı Hazır Duvar Paneli Genel Özellikleri}

Geliştirilen radyant hibrid duvar paneli sistemi ısıl performans için borular arası mesafe, panel ve yalıtım kalınlıkları ile dış cephe kaplama malzeme seçim çalışmaları yapılmıştır. Bina statik yüküne ağırlık oluşturmayacak şekilde hafif, taşınımı ve uygulaması kolay ve radyal boruların içerisinde yer alacağı kalınlık ve kesite sahip panel ön tasarım çalışmaları gerçekleştirilmiştir. İstanbul İmar Yönetmeliği'nin önerdiği oda ölçüleri ve yükseklik verileri üzerinden yapılan değerlendirme ile panel boyut ve malzeme seçimlerine karar verilmiştir. Yapılan araştırmalar sonucunda sistemin modülerliği açısından panel boyutlandırmada, genişlik için 60 ve $120 \mathrm{~cm}$, yükseklik için ise İstanbul İmar Yönetmeliğinde önerilen 2.80 ve $3.00 \mathrm{~m}$ olarak belirlenmiştir. ${ }^{12}$

Panel malzeme seçim kararlarında ise; iç yüzeylerde alçı levhalar tercih edilmiştir. Hafif, kolay şekil alabilen ve yangına dayanıklı malzemeler olması sayesinde uygun bulunan bu malzeme arasına EPS ise, yalıtım ve dolgu malzemesi olarak kullanılmıştı. Su emicilik değeri düşük, darbe emme değeri yüksek ve kullanımda kolaylık sağlayan bu malzeme aynı zamanda radyal boruların içerisine gizlendiği bir katman özelliğini de göstermektedir. Duvar dış yüzeylerinde tercih edilen fibercement levhalar ise su-yangın direnci özellikleri ile cepheye dair estetik kaygılara olumlu cevap vermesi yönünden tercih edilmiştir. Bu çalışmalar sonucunda elde edilen iç, dış ve tamamlayıcı duvar panelleri teknik çizimleri Şekil 1 ve 2'de görüldüğü gibidir.

\footnotetext{
${ }^{10}$ Gedik vd., 2016. ${ }^{11}$ Gedik vd., 2014. ${ }^{12}$ İstanbul İmar Yönetmeliği, 2008
} 


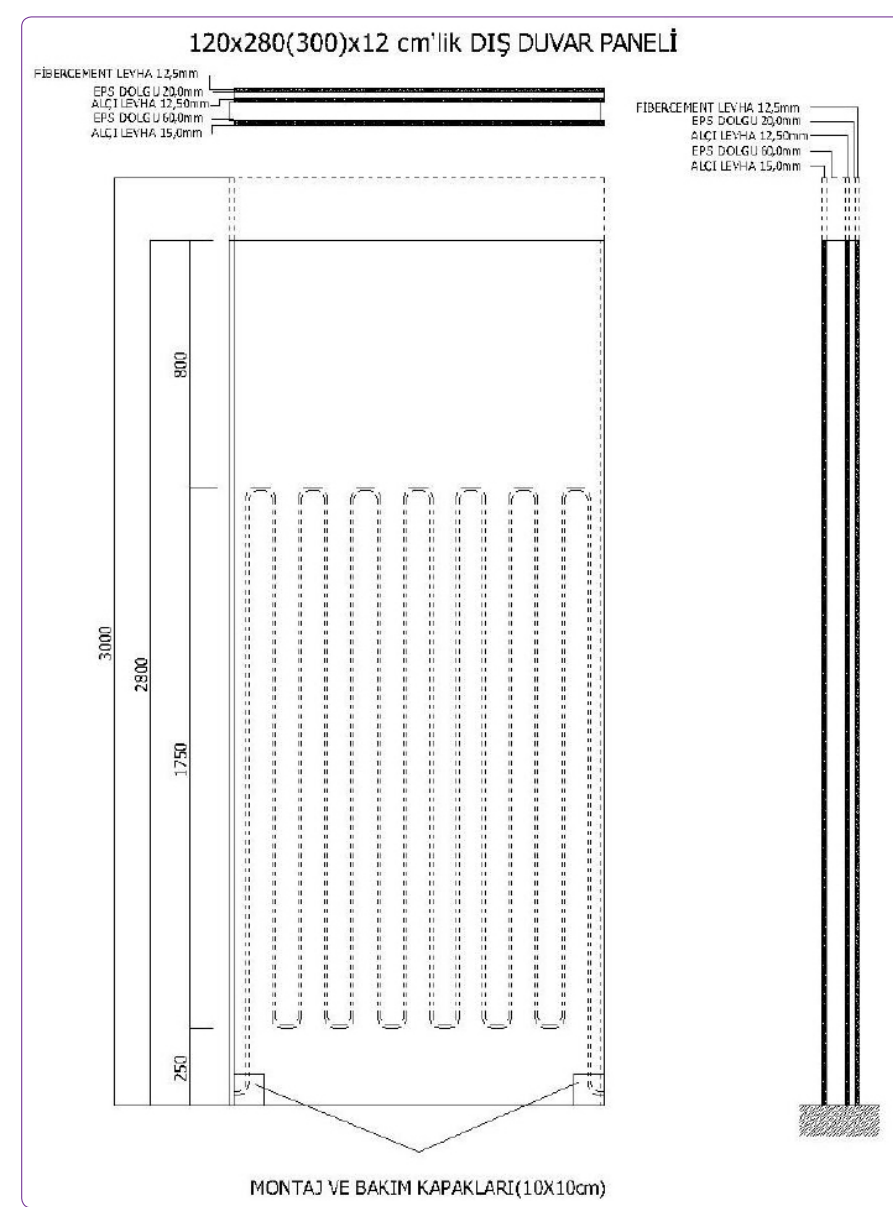

Şekil 2. $120 \times 280(300) \times 12 \mathrm{~cm}^{\prime}$ lik Dış Duvar Paneli. ${ }^{10}$

\section{Yöntem}

Kapsamı sınırlandırıımış olan bu çalışmada, hazır duvar elemanları ile geleneksel tipte yapılmış duvar elemanları karşılaştırması gerçekleştirilmiştir. Bu karşılaştırma için oluşturulan yaklaşımın ölçütleri ve aşamalarını içeren akış diyagramı Şekil 3'de verilmiştir.

Yapı elemanı olarak ele alınan duvarlar için performans kriterlerini oluşturan özellikler belirlenmiş ve mevcut bir ofis yapısı için incelenmiştir. Ofis binaları işlev, teknik ve finansal etkenlere bağlı olarak çeşitli kategorilerde sınıflandırımaktadırlar. Kat sayılarına göre;

- az katlı (7 kattan az),

- orta katlı (7-25 kat arası) ve

- yüksek katı (25 kattan fazla) şeklinde sınıflandırılmaktadırlar. ${ }^{13}$

Bina Sahipleri ve Yöneticileri Kuruluşu (BOMA) ise ofis binalarını mimari-teknik özellikler, konum ve kiralama bedeli kriterlerine göre;

- A sınıfi (prestijli ofis),

- B sınıfi (standart ofis),

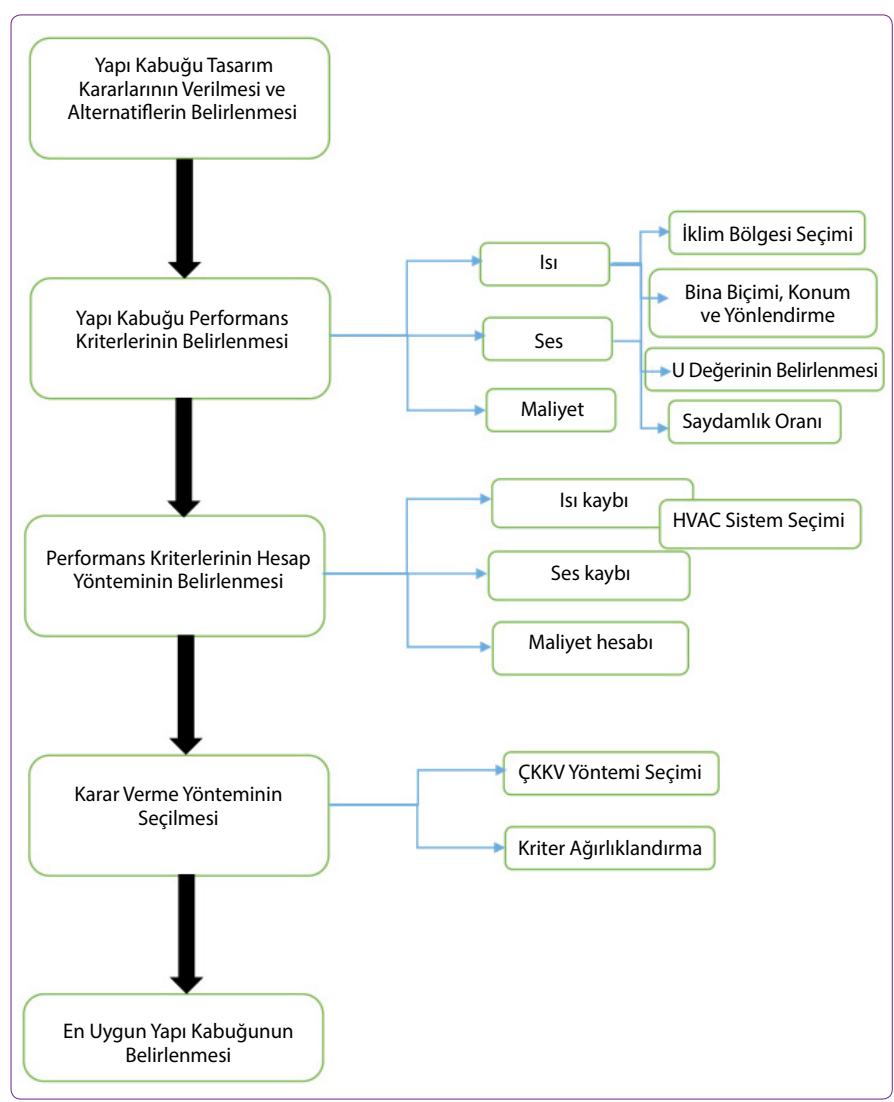

Şekil 3. Yapı kabuğu tasarımı için önerilen yaklaşımının akış şeması.

- C sınıf (klasik ofis) olarak sınıflandırmaktadır. ${ }^{14}$

İşlev ve kullanıma bağlı olarak yapılan bir diğer sınıflandırma ise, idari ve ticari ofis binaları olmak üzere iki kategoriden oluşmaktadır. İari ofis binaları; endüstri, siyasi ve kültürel alanlara hizmet eden kamu kurumları ve özel kuruluşlardır. Ticari ofis binaları ise; bölümleri ayrı departman ve/veya kurumlara kiralanabilen yapılardır. ${ }^{15}$

Planlama biçim ve türlerine göre ise;

- hücre planlı,

- grup planlı,

- açık planlı,

- serbest planlı ve

- karma planlı

olarak kategorizasyon yapılmıştr. Çekirdek ve koridorun plan içerisindeki konumu, planlama tipleri açısıdan en önemli farklılığı oluşturmaktadır. ${ }^{16}$

Çalışmada orta katlı, B sınıfı ve açık planlı bir ticari ofis binası kullanılmıştır. Yaklaşımın örneği olarak belirlenen ofis yapısı İstanbul Ümraniye'de yer alan bir ofis binasıdır. 4 adet bodrum kat, zemin kat ve 8 normal kattan oluşan bu ofis binası $64,2 \times 35,6 \mathrm{~m}$ ölçülerinde dikdörtgen bir plan şemasına sahiptir. $2285 \mathrm{~m}^{2}$ taban alanına sahip olan 4 bod-

${ }^{14}$ Building Class Definitions. [Online]. $\quad{ }^{15}$ Eldem, 1950. $\quad{ }^{16}$ Karslı, 2008. 


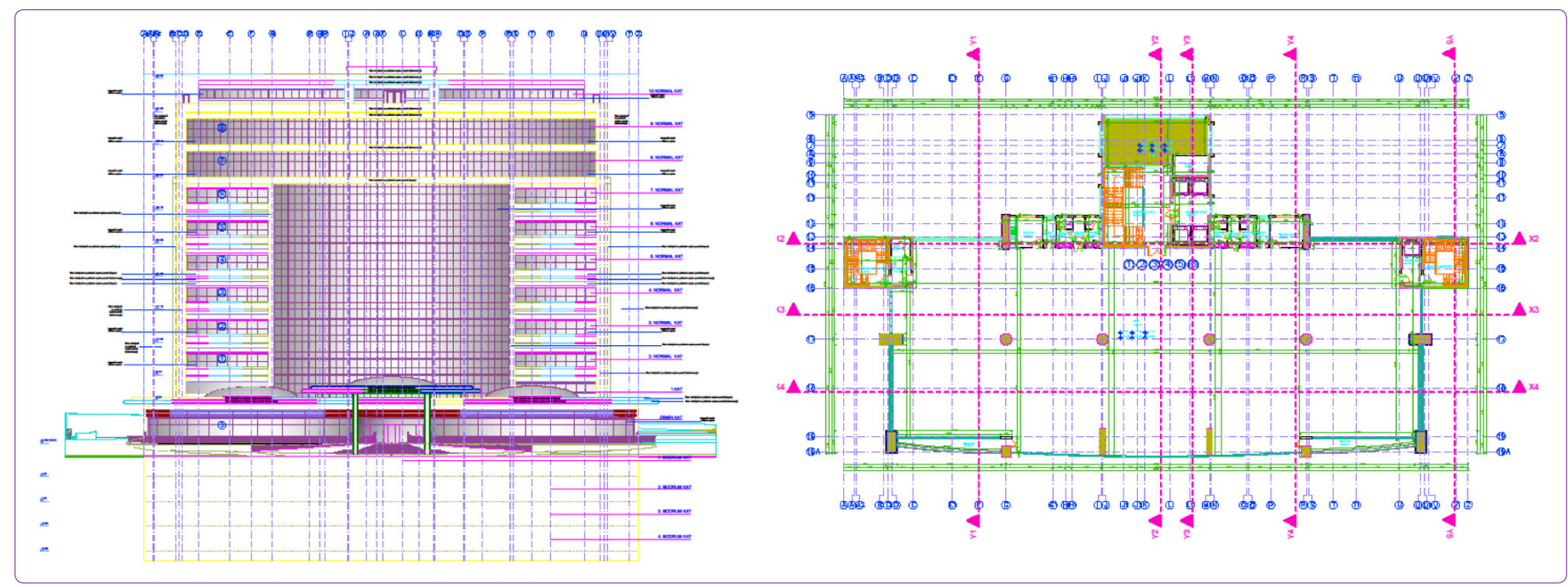

Şekil 4. Ofis binası ön görünüş ve normal kat planı.

rum ve 8 kattan oluşan bina cam giydirme cepheye sahiptir. Dikdörtgen plan şemalı bina, zemin ve üzeri katlar için değerlendirilmiştir. Mevcut bina plan ve ön görünüşü Şekil 4'te verilmiştir.

\section{Yapı Kabuğu Alternatiflerinin Belirlenmesi}

Karşılaştırma yapılacak duvar tiplerine karar verilmesinde öncelikle mevcut binanın cam giydirme cephe olması özelliği dikkate alınarak mevcut durum seçenek olarak aynen kullanılmıştir. 0462.STZ.2013-2 no'lu SAN-TEZ projesi kapsamında, ön tasarım ve deneysel çalışmalarla belirlenen yüzeyden ısıtma-soğutma sistemli optimum modüler duvar elemanı kesiti aynen alınmıştır. Diğer alternatif kesitlerin belirlenmesinde uygulamada en çok kullanılan yalıtımlı tuğla ve gaz beton duvar ve de çok katmanlı hava boşluklu taş kaplamalı duvar seçenekleri oluşturulmuştur. Bu seçeneklerin oluşturulmasında TS 825 standartının iklim bölgelerine göre dış duvarlar için belirlediği U değerinin sınır değerlerine uygunluk esas alınmıştır. Gerçekte sık uygulanan kesitler seçilerek, yalıtım kalınlığı ve türü eşit tutulmuştur. Kesitin ana gövde elemanlarının kalınlıkları üretimdeki boyutları esas alınarak ve birbirine yakın tutularak, toplam kesit detayı oluşturulmuştur.

Dolayısıyla kesitlerin $U$ değerleri ve kalınlıkları kesitin kuruluş yapısına ve uygulama detayına göre az da olsa farklılık göstermektedir. Kesit seçiminde mevcutta uygulanan detaylar esas alınmıştır. Yapı elemanını oluşturan malzeme detayları ve duvar kesit kalınlığı gibi teknik özellikler Tablo 1 'de gösterilmektedir.

\section{Yapı Kabuğu Performans Kriterlerinin Belirlenmesi}

Tüm yapı elemanlarının değerlendirilmesinde; öncelikle yapı elemanına ait performans ölçütleri belirlenmelidir. Daha sonra bu ölçütlere göre olası seçeneklerin değerlendirilmesi ve uygunluk derecelerine göre çözümlerin ortaya konulması gerekir.
Radyant sisteme sahip hazır duvar elemanlarından oluşan bu yapılarda

- ISI,

- ses ve

- maliyet

parametreleri hesap değerleri ortaya konulmuş ve geleneksel tuğla duvara sahip bina, giydirme cam cepheye sahip bina, taş kaplama tuğla ve gaz beton duvar ile karşılaştırmalar yapılmıştır.

- Isı açısından değerlendirmede gerçek atmosfer koşullarında saatlik dinamik hesap yöntemi kullanılmıştır. Araç olarak EnergyPlus ara yüzü kullanan Design Builder programı kullanılmıştr.

- Karayolu trafik gürültüsünün $75 \mathrm{dbA}$ olduğu durum için içeri geçen gürültü düzeyi hesaplamaları "Insul" yazılımı aracılığıyla yapılmıştır.

- Maliyet kriteri ise, Net Bugünkü Değer (NBD) yöntemi ile bulunmuştur.

Performans kriterleri hesaplamaları, bazı kabul ve veriler eşliğinde gerçekleştirilmiştir. Kabuller aşağıda sıralanmaktadır.

- Cephe tasarımında saydamlık oranlarında güney \%50, doğu-bat \%30 ve kuzey \%20 olarak alınmıştr.

- Anayollardaki ofis binaları için geçerli düzey olan 75 $\mathrm{dbA}$ dış gürültü düzeyi sabit alınmıştır. ${ }^{17}$

- Ses kayıp analizlerinde, saydamlık oranı en yüksek olan güney cephesi karayolu trafik gürültüsüne maruz kalan yön olarak kabul edilmiştir.

- Çalışma kapsamında kriterler açısından "Isı kaybı" ve "İçeri geçen ses düzeyi" eşit ağırlıkta öncelik verilerek ele alınmıştır. Ardından "Maliyet" parametresi daha az ağırlık oranı ile değerlendirilmiştir.

17 EN 1793-3, 1997. 
Tablo 1. Alternatif duvar kesitleri teknik özellikleri

\begin{tabular}{|c|c|c|c|c|c|}
\hline Alternatif kesitler & Yapı Elemanları & $\begin{array}{l}\text { Yapı Elemanı } \\
\text { Kalınlığı } \\
\text { L (m) }\end{array}$ & $\begin{array}{c}\text { Isıl iletkenlik } \\
\text { hesap değeri } \\
\lambda(\mathrm{W} / \mathrm{mK})\end{array}$ & $\begin{array}{c}\text { Kesit } \\
\text { kalınlığı } \\
(\mathbf{m})\end{array}$ & $\begin{array}{c}\text { Toplam Isı } \\
\text { Geçiş Katsayısı } \\
\mathbf{U}\left(\mathbf{W} / \mathbf{m}^{2} \mathbf{K}\right)\end{array}$ \\
\hline Radyant hibrid & Betopan & 0,012 & 0,20 & 0,12 & 0,38 \\
\hline \multirow[t]{4}{*}{ duvar } & EPS (Ekstrüde Polistren Köpük) & 0,020 & 0,035 & & \\
\hline & Alçı levha & 0,012 & 0,25 & & \\
\hline & EPS (Ekstrüde Polistren Köpük) & 0,060 & 0,035 & & \\
\hline & Alçı levha & 0,015 & 0,25 & & \\
\hline Geleneksel tuğla & Kireç harcı, kireç-çimento harcı & 0,03 & 1 & 0,27 & 0,60 \\
\hline \multirow[t]{4}{*}{ dış duvar } & EPS (Ekstrüde Polistren Köpük) & 0,03 & 0,035 & & \\
\hline & Düşey delikli tuğlalarla yapılan & & & & \\
\hline & duvarlar (TS EN 771-1) & 0,19 & 0,42 & & \\
\hline & Alçı sıva - perlit esaslı & 0,02 & 0,14 & & \\
\hline \multirow[t]{2}{*}{ Giydirme cam } & $6 \mathrm{~mm}$ mavi Reflekte temperli + & & & & \\
\hline & $16 \mathrm{~mm} \mathrm{HB}+4 \mathrm{~mm}$ Low - E Cam & 0,026 & 2,2 & 0,026 & 2,2 \\
\hline Taş kaplamalı & Taş kaplama & 0,115 & 1,3 & 0,365 & 0,47 \\
\hline \multirow[t]{5}{*}{ dış duvar } & Hava boşluğu & 0,01 & 0,025 & & \\
\hline & EPS (Ekstrüde Polistren Köpük) & 0,03 & 0,035 & & \\
\hline & Düşey delikli tuğlalarla yapılan & & & & \\
\hline & duvarlar (TS EN 771-1) & 0,19 & 0,42 & & \\
\hline & Alçı sıva - perlit esaslı & 0,02 & 0,14 & & \\
\hline Gaz beton & Kireç harcı, kireç-çimento harcı & 0,03 & 1 & 0,28 & 0,39 \\
\hline \multirow[t]{4}{*}{ dış duvar } & EPS (Ekstrüde Polistren Köpük) & 0,03 & 0,035 & & \\
\hline & $\begin{array}{l}\text { Buharla sertleştirilmiş gaz betonlar } \\
\text { (TS EN 771-4'e uygun yapı }\end{array}$ & & & & \\
\hline & elemanları dâhil) & 0,2 & 0,15 & & \\
\hline & Alçı sıva - perlit esaslı & 0,02 & 0,14 & & \\
\hline
\end{tabular}

\section{Isı Kaybı Hesaplamaları}

\section{- İklim Bölgesinin Belirlenmesi}

Bu çalışmanın kapsamı ılıman nemli iklim bölgesinden (Türkiye 2. Derece gün (DG) bölgesinden) İstanbul ile sınırlandırımıştır. Türkiye 4 derece gün bölgesinden istenilen bölge ve il seçimi ile ilerideki çalışmalar çeşitlilik kazanabilecektir.

Çalışma kapsamında her bir duvar örneği için toplam ISı kaybı hesabı, yıllık bazda 1 Ocak - 31 Aralık tarihleri aralığında 20-25 yıllık iklim verileri ortalamasından oluşan iklim data dosyası kullanılarak Design Builder programı ile gerçekleştirilmiştir. ${ }^{18}$ Program, ASHRAE onaylı ısıl denge yöntemini EnergyPlus yazılımından uyarlayarak kullanmaktadır. Binanın bulunduğu şehir, bina kullanım türü ve kullanıcı sayısı, mekân tanımlamaları, bina kabuğu opak ve saydam bileşen detayları, ısıtma, soğutma, aydınlatma ve iklimlendirme sistemlerine ilişkin veriler kullanılarak ve binayı üç boyutlu olarak modelleyerek enerji hesabı yapılmıştir. ${ }^{19}$ Istanbul ili ısıtma alt ve üst limit değerleri radyant hibrid duvar için $12-18{ }^{\circ} \mathrm{C}$, diğer duvar tipleri için $12-20^{\circ} \mathrm{C}$

\footnotetext{
${ }^{18} \mathrm{https}$ ///www.youtube.com/watch?v=S2zBO7CBweg, 2019.

${ }^{19}$ Design Builder Software, 2006.
}

olarak seçilmiştir. Çünkü radyant sistemlerde ortalama ışınımsal sıcaklık değeri yüksek olduğundan hava üst sıcaklık set değeri diğer konvensiyonel sistemlere göre düşük seçilmiştir. Genel prensip olarak, ışınım ile ısıtma-soğutma yapan sistemlerde ısı kaybı mahal içerisinden değil, panellerden gerçekleşmektedir. ${ }^{20}$

Programda yer alan HVAC (Heating Ventilating and Air Conditioning) sistem türlerinden her bir duvar alternatifi için uygun olan seçilmiştir. Bu seçimde Isıtma sisteminin ısıl dağıtım özellikleri, mekânda uygulama biçimi ve yerinin yapı kabuğu ile uyumu gibi özellikler dikkate alınmıştır. Her bir duvar türü alternatifine ve mekân-malzeme birlikteliğine uygun olacak şekilde seçilen HVAC sistemlerin farklılaşthğı görülmektedir. Geleneksel ve kaplama duvar türlerinde "Radyatör" ile ısıtma tercih edilirken, giydirme cam cephe binada "Split klima" lar kullanılmıştır. Radyant hibrid duvar türünde ise sisteme sıcak su boruları ile girdi sağlayan "Isı Pompası ile ısıtma türü kullanılmıştır. Tablo 2'de alternatif kesitler için seçilen HVAC sistem türleri ve DB'de gerçekleştirilen ısı kayıp analiz sonuçları (kW) yer almaktadır.

\footnotetext{
${ }^{20}$ Koca vd., 2014.
} 
Tablo 2. Design Builder programı ısı kayıp analizleri sonuçları

\begin{tabular}{lcc}
\hline Alternatif kesitler & HVAC sistem türü & $\begin{array}{r}\text { Toplam Isı } \\
\text { kaybı (kW) }\end{array}$ \\
\hline $\begin{array}{l}\text { Radyant hibrid } \\
\text { duvar }\end{array}$ & $\begin{array}{r}\text { GSHP-Ground Source } \\
\text { Geleneksel tuğla } \\
\text { dış duvar }\end{array}$ & 669,38 \\
$\begin{array}{l}\text { Giydirme cam } \\
\text { Radiator Heating, }\end{array}$ & 942,10 \\
$\begin{array}{l}\text { Taş kaplamalı dış } \\
\text { duvar }\end{array}$ & $\begin{array}{r}\text { Fan Coil Unit (4-Pipe), } \\
\text { Air Cooled Chiller } \\
\text { Gaz beton duvar }\end{array}$ & 1054,63 \\
& $\begin{array}{r}\text { Radiator Heating, } \\
\text { Boiler HW, Nat Vent. } \\
\text { Radiator Heating, }\end{array}$ & 921,8 \\
& Boiler HW, Nat Vent. & 660,48 \\
\hline
\end{tabular}

Tablo 3. İçeri geçen gürültü düzeyi

\begin{tabular}{lcc}
\hline Alternatif kesitler & $\begin{array}{c}\text { Dış gürültü } \\
\text { düzeyi } \\
\text { (dBA) }\end{array}$ & $\begin{array}{c}\text { iç̧eri geçen } \\
\text { ses düzeyi } \\
\text { (dbA) }\end{array}$ \\
\hline Radyant hibrid duvar+cam & 75 & 38 \\
Geleneksel tuğla dış duvar+cam & 75 & 37 \\
Giydirme cam cephe & 75 & 40 \\
Taş kaplamalı dış duvar+cam & 75 & 37 \\
Gaz beton duvar +cam & 75 & 37 \\
\hline
\end{tabular}

\section{Ses Kaybı Hesaplamaları}

Ofis binasının anayol kenarında, dış gürültü seviyesinin 75 dbA kabul edildiği bir lokasyanda yer aldığı kabul edilmektedir. İçeri geçen gürültü düzeyi hesaplamaları ise Insul yazılımı aracılığıyla gerçekleştirilmiştir. Hesaplamalar sonucunda 30082 sayılı Binalarin Gürültüye Karşi Korunmasi Hakkinda Yönetmelik (Binalarda Ses Yalıtımı) çerçevesinde

- Gürültüye Karşı Hassasiyetin ve Gürültülülük Derecesinin Belirlenmesi (yönetmelik Ek 2)

- Binalarda İzin Verilen İç Gürültü Düzeyleri (yönetmelik Ek 4)

- Binalarda İzin Verilen Reverberasyon Süreleri (yönetmelik Ek 6) uygulama örneği için gerekli kontroller sağlanmıştir. ${ }^{21}$

Tablo 3'de duvar kesit türlerine göre içeri geçen ses düzeyleri (dbA) yer almaktadır.

\section{Maliyet Analizi Hesaplamaları}

Bina ekonomik ömrünün 30 yıl olduğu kabulü ile maliyet hesabı Net Bugünkü Değer (NBD) yöntemi ile hesaplanmıştır. NBD, yatırımın işletim ömrü boyunca sağladığı getirinin bugünkü değerinden yatırım giderlerinin bugünkü değeri-

\footnotetext{
${ }^{21}$ Binaların Gürültüye Karşı Korunması Hakkında Yönetmelik, 2017.
}

nin düşülmesi sonucunda elde edilen farkı ifade etmektedir. ${ }^{22}$ Bu yöntem, projenin karlııı̆ını analiz etmek açısından önemlidir. Maliyet hesaplamalarını oluşturan değerler 6 adımdan meydana gelmektedir. Bunlar;

- Ilk yatırım maliyeti (kabuk ve ısıl maliyet)

- Yakıt maliyeti

- Elektrik tüketim maliyeti

- Yıllık Bakım maliyeti

- Genel bakım maliyeti ve

- Duvar kalınlık maliyet etkisi olarak sıralanmıştır.

Tüm bina kabuğu ve ısıtma-soğutma sistem ekipman maliyet verileri Çevre Şehircilik Bakanlığı Döner Sermaye İşletmesi Müdürlüğü 2019 yılı birim fiyat listesinden alınarak, hesaplamalarda kullanılmıştır. ${ }^{23}$ Yıllık yakıt maliyeti hesabı ise,

$$
B_{y}=\frac{Q_{y l l}}{H_{u} x \eta_{k}}
$$

formülü ile 120 kW ısıl kapasiteli, duvar tipi yoğuşmalı kazan seçimi ile oluşturulmuştur.

By yıllık yakıt sarfiyatını ( $\left.\mathrm{m}^{3} / \mathrm{yll}\right)$, Qyıl yıllık ısı enerjisi ihtiyacını (kJ), Hu yakıt olarak kullanılacak doğalgazın üst ısıl değerini ve $n$ ise yakıt verimini (\%) ifade etmektedir. Yakıt olarak doğalgaz tüketimi belirlenmiş ve IGDAŞ verileri esas alınarak hesaplamalarda kullanılmıştır.

Elektrik maliyeti hesabında, Enerji Piyasası Düzenleme Kurulu (EPDK) tarafindan belirlenmiş olan güncel birim fiyat verisi kullanılarak yapılmıştı. Haftasonları ve resmi tatiller hariç ayda 20 gün ve günlük 10 saatlik çalışma zaman dilimleri esas alınarak tüketim hesaplanmıştır.

30 yıllık sistem yatırım ömrüne sahip bu binanın genel bakımlarının 10 yılda bir, yıllık bakım maliyetleri ise duvar türlerine göre piyasa verilerinden elde edilerek, hesaplamalara katılmıştır. Merkez Bankası güncel verilerinden yıllık faiz oranı (i) \%18 ve doğalgaz ile yıllık bakım değişim oranı (g, eskalasyon oranı) \%3 ve elektrik değişim oranı \%2 olarak alınmıştir.

Şekil 5'te Maliyet hesaplamalarını oluşturan girdiler eskalasyon (g) oranları ile birlikte görülmektedir.

Piyasalardan alınan güncel veriler aşağıdaki gibidir.

- Doğalgaz birim fiyatları $1,15 \mathrm{TL} / \mathrm{m}^{3}$ olarak IGDAŞ'ın 01.04.2019 tarihli güncel verilerinden alınmıştır. ${ }^{24}$

- Elektrik birim fiyatları ise 0,41542 TL olarak EPDK'dan 01.04.2019 tarihinden itibaren geçerli olmak üzere alınmıştr. ${ }^{25}$

- Sistem ekonomik ömrü olarak 30 yıl belirlenmiştir.

\footnotetext{
${ }^{22}$ http:/www.fizibilite.info/net- ${ }^{24}$ https://www.igdas.istanbul/perabugunku-deger/, 2019.

${ }^{23} 2019$ Yılı İnşaat ve Tesisat Birim Fi- ${ }^{25}$ https://www.epdk.org.tr/Detay/ yatları, 2019.
} 
Tablo 4. Net Bugünkü Değer (NBD) yöntemi maliyet hesabı sonuçları

\begin{tabular}{|c|c|c|c|c|c|c|c|}
\hline Alternatif kesitler & $\begin{array}{c}\text { ilk yat. } \\
\text { (kabuk+ısıl)- } \\
\text { TL }\end{array}$ & $\begin{array}{c}\text { Yakıt } \\
\text { maliyeti-TL }\end{array}$ & $\begin{array}{l}\text { Elektrik } \\
\text { Tük. -TL }\end{array}$ & Bakım - TL & $\begin{array}{c}\text { Genel } \\
\text { Bakım - } \\
\text { TL }\end{array}$ & $\begin{array}{c}\text { Kesit - } \\
\text { Maliyet } \\
\text { katkısı -TL }\end{array}$ & $\begin{array}{c}\text { NBD } \\
\text { maliyet - } \\
\text { TL }\end{array}$ \\
\hline Radyant hibrid duvar & 1.374 .631 & $85.262,98$ & $1.312 .164,86$ & $11.593,50$ & 111.000 & $11.287,14$ & $2.905 .939,48$ \\
\hline Geleneksel tuğla dış duvar & 1.304 .956 & $161.263,03$ & $1.312 .164,86$ & 15.458 & 83.250 & $27.813,67$ & $2.904 .905,56$ \\
\hline Cam cephe & 3.476 .475 & 0 & $1.790 .558,30$ & 23.187 & 166.500 & 0 & $5.456 .720,30$ \\
\hline Taş kaplamalı dış duvar & 1.426 .831 & $134.289,37$ & $1.312 .164,86$ & 15.458 & 83.250 & $43.498,05$ & $3.015 .491,28$ \\
\hline Gaz beton duvar & 1.423 .858 & $84.144,76$ & $1.312 .164,86$ & 15.458 & 83.250 & $31.591,43$ & $2.950 .467,05$ \\
\hline
\end{tabular}

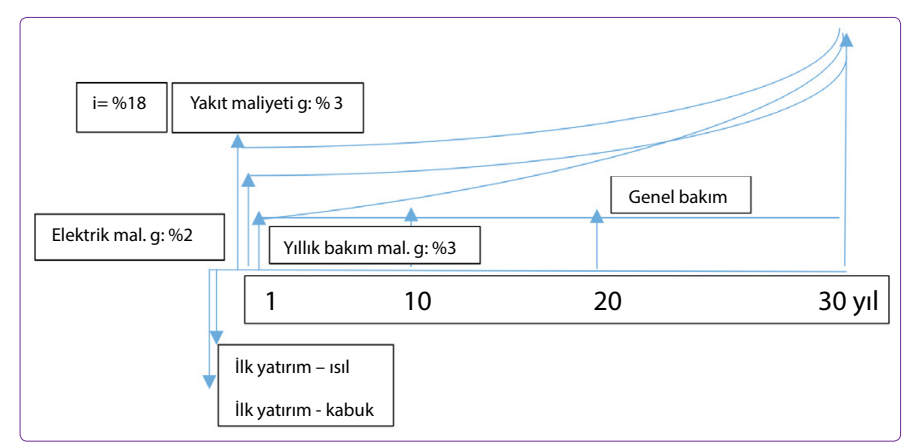

Şekil 5. Maliyet hesap verileri ayrıntılı grafiği.

- TC. Merkez Bankası yıllık faiz oranı \%18 olarak 21.09.2018 tarihli güncel verilerinden alınmıştır. ${ }^{26}$

- Duvar kalınlığının maliyet etkisi ise duvar birim maliyetlerinin, birbirlerine göre $\mathrm{cm}$ cinsinden kalınlıkları oranlanarak bulunmuş ve maliyet hesaplamalarına bir parametre olarak eklenmiştir.

Tablo 4'de Net Bugünkü Değer (NBD) Yöntemi ile hesaplanan duvar kesitlerine ait bina maliyetleri yer almaktadır.

En Uygun Yapı Kabuğunun Belirlenmesi için Uygun Karar Verme Yöntemi Seçimi

Yapı kabuğu alternatifleri için ortaya çıkan performans değerleri belirlenen Çok Kriterli Karar Verme (ÇKKV) yöntemi TOPSIS ile ortaya konularak, en uygun kesit seçimi yapılmıştır. Yöntem seçiminde günlük hayatımızda da uyguladığımı TOPSIS, seçeneklerin belli olduğu ve kriterlere göre karar verilmesi gereken bu çalışma için uygun bulunmuştur. Literatürde binlerce yayına konu edilmiş olan ve politika seçimi, sistem karşılaştırması, helikopter seçimi vb. konularda yararlanılan TOPSIS yöntemi- İdeal Çözüme Benzerlik Yoluyla Sıralama Tercihi Tekniği (Technique for Order Preference by Similarity to Ideal Solution) Yoon ve Hwang tarafindan 1980 yılında geliştirilen bir ÇKKV (Çok Kriterli Karar Verme) tekniğidir. ${ }^{27}$ Karar noktalarının ideal çözüme yakınlığı ana prensibine dayanır. Farklı alternatif-

${ }^{26}$ https://www.tcmb.gov.tr/wps/wcm/connect/tr/tcmb+tr/main+menu/ temel+faaliyetler/para+politikasi/merkez+bankasi+faiz+oranlari

${ }^{27}$ http://www.deu.edu.tr/userweb/k.yaralioglu/dosyalar/TOPSIS_Yontemi. doc, 2019. lerin bulunduğu problemlerin çözümünde kullanılan çok kriterli karar verme teknikleri (ÇKKV), sorunu tanımlama, alternatifler üretme ve kriterleri oluşturma, kriter seçimi, kriter ağırlıklandırma, değerlendirme, uygun çok kriterli yöntemi seçme ve alternatiflerin sıralanması şeklinde sıralı aşamaları izler.

Topsis yöntemi 6 adımdan oluşan bir çözüm sürecini içermektedir. Sırasıyla Karar matrisi (A), Standart Karar Matrisi (R), Ağırlıklı Standart Karar Matrisi (V), İdeal (A*) ve Negatif İdeal Çözümler (A-), Ayrım Ölçümleri (Si*, Si-) ve İdeal Çözüme Göreli Yakınlık $\left(\mathrm{Ci}^{*}\right)$ hesaplamaları sonucunda ele alınan kesitler arasında en uygunu elde edilmiştir.

\section{Adım Karar Matrisi}

Karar matrisinin satırlarında üstünlükleri sıralanmak istenen karar noktaları, sütunlarında ise karar vermede kullanılacak değerlendirme faktörleri yer alır. ${ }^{27}$

$$
A_{i j}=\left[\begin{array}{cccc}
a_{11} & a_{12} & \ldots & a_{1 n} \\
a_{21} & a_{22} & \ldots & a_{2 n} \\
\cdot & & & \cdot \\
\cdot & & & \cdot \\
\cdot & & & \cdot \\
a_{m 1} & a_{m 2} & \ldots & a_{m n}
\end{array}\right]
$$

$A_{i j}$ matrisinde $\mathrm{m}$ karar noktası sayısını, $\mathrm{n}$ değerlendirme faktörü sayısını verir.

Tablo 5'de beş duvar alternatifi için hesaplanan ısı kaybı, ses kaybı ve maliyet hesap sonuçları yer almaktadır.

\section{Adım Standart Karar Matrisi}

Standart Karar Matrisi, A matrisinin elemanlarından yararlanarak ve aşağıdaki formül kullanılarak hesaplanır. ${ }^{27}$

$$
r_{i j}=\frac{a_{i j}}{\sqrt{\sum_{k=1}^{m} a_{k j}^{2}}}
$$

\footnotetext{
${ }^{27} \mathrm{http}: / /$ www.deu.edu.tr/userweb/k.yaralioglu/dosyalar/TOPSIS_Yontemi. doc, 2019.
} 
Tablo 5. Karar Matrisi

\begin{tabular}{lccc}
\hline Alternatifler & \multicolumn{3}{c}{ Kriterler } \\
\cline { 2 - 4 } & $\begin{array}{c}\text { Isı } \\
\text { kaybı } \\
\text { (kW) }\end{array}$ & $\begin{array}{c}\text { içeri geçen } \\
\text { ses düzeyi } \\
\text { (dbA) }\end{array}$ & $\begin{array}{c}\text { NBD } \\
\text { maliyeti } \\
\text { (TL) }\end{array}$ \\
\hline Hibrid duvar & 669,38 & 38 & $2.905 .939,48$ \\
Tuğla duvar & 942,10 & 37 & $2.904 .905,56$ \\
Giydirme cam & 1054,63 & 40 & $5.456 .720,30$ \\
Taş kaplama duvar & 921,8 & 37 & $3.015 .491,28$ \\
Gaz beton duvar & 660,48 & 37 & $2.950 .467,05$ \\
\hline
\end{tabular}

$$
R_{i j}=\left[\begin{array}{cccc}
r_{11} & r_{12} & \ldots & r_{1 n} \\
r_{21} & r_{22} & \ldots & r_{2 n} \\
\cdot & & & \cdot \\
\cdot & & & \cdot \\
\cdot & & & \cdot \\
r_{m 1} & r_{m 2} & \ldots & r_{m n}
\end{array}\right]
$$

Karar matrisi oluşturulduktan sonra normalizasyon işlemi (rij) gerçekleştirilir. Bu adımda amaç, kriter sayısal değerlerinin 0 ila 1 arasında karşılaştırılabilir sayısal değerlere dönüştürülmesidir.

Tablo 6'da 0 ila 1 arasında sayısal değerlere dönüştürülen hali ile duvar alternatiflerine ait kriterler görülmektedir.

\section{Adım Ağırlıklı Standart Karar Matrisi}

Öncelikle değerlendirme faktörlerine ilişkin ağırlık değerleri $\left(w_{i}\right)$ belirlenir.

$$
\sum_{i=1}^{n} w_{i}=1
$$

Daha sonra R matrisinin her bir sütunundaki elemanlar ilgili değeri ile çarpılarak $V$ matrisi oluşturulur. ${ }^{27}$

Normalize matris ile elde edilen nij değerleri, wij ağırlıkları ile çarpılarak ağırlıklandırılmış normalize matris (V matrisi) elde edilir.

$$
V_{i j}=\left[\begin{array}{cccc}
w_{1} r_{11} & w_{2} r_{12} & \ldots & w_{n} r_{1 n} \\
w_{1} r_{21} & w_{2} r_{22} & \ldots & w_{n} r_{2 n} \\
\cdot & & & \cdot \\
\cdot & & & \cdot \\
\cdot & & & \cdot \\
w_{1} r_{m 1} & w_{2} r_{m 2} & \ldots & w_{n} r_{m n}
\end{array}\right]
$$

Çalışmada öncelikli kriter sıralaması (ısı kaybı-0,4, ses kaybı-0,4 ve maliyet-0,2) ağırlık değeri verilerek oluşturu-

${ }^{27}$ http://www.deu.edu.tr/userweb/k.yaralioglu/dosyalar/TOPSIS_Yontemi. doc, 2019.
Tablo 6. Standart Karar Matrisi

\begin{tabular}{lccc}
\hline Alternatifler & \multicolumn{3}{c}{ Kriterler } \\
\cline { 2 - 4 } & $\begin{array}{c}\text { Isı } \\
\text { kaybı } \\
\text { (kW) }\end{array}$ & $\begin{array}{c}\text { İçeri geçen } \\
\text { ses düzeyi } \\
\text { (dbA) }\end{array}$ & $\begin{array}{c}\text { NBD } \\
\text { maliyeti } \\
\text { (TL) }\end{array}$ \\
\hline Hibrid duvar & 0,34641469 & 0,449366 & 0,361951887 \\
Tuğla duvar & 0,48755159 & 0,437541 & 0,361823107 \\
Giydirme cam & 0,54578764 & 0,473017 & 0,679666671 \\
Taş kaplama duvar & 0,47704602 & 0,437541 & 0,37559721 \\
Gaz beton duvar & 0,3418088 & 0,437541 & 0,367498059
\end{tabular}

Tablo 7. Ağırlıklı Standart Karar Matrisi

\begin{tabular}{lccc} 
ağırlık & $\mathbf{0 , 4}$ & $\mathbf{0 , 4}$ & $\mathbf{0 , 2}$ \\
\hline Alternatifler & \multicolumn{3}{c}{ Kriterler } \\
\cline { 2 - 4 } & $\begin{array}{c}\text { Isı } \\
\text { kaybı } \\
\text { (kW) }\end{array}$ & $\begin{array}{c}\text { İçeri geçen } \\
\text { ses düzeyi } \\
\text { (dbA) }\end{array}$ & $\begin{array}{c}\text { NBD } \\
\text { maliyeti } \\
\text { (TL) }\end{array}$ \\
\hline Hibrid duvar & 0,13856588 & 0,179746 & 0,072390377 \\
Tuğla duvar & 0,19502064 & 0,175016 & 0,072364621 \\
Giydirme cam & 0,21831505 & 0,189207 & 0,135933334 \\
Taş kaplama duvar & 0,19081841 & 0,175016 & 0,075119442 \\
Gaz beton duvar & 0,13672352 & 0,175016 & 0,073499612
\end{tabular}

lan "Ağırlıklı Standart Karar Matrisi" Tablo 7'de yer almaktadır.

*Çalışmada, Ağırlıklı Standart Karar Matrisi oluşturulurken ağırlık değerleri ısı kaybı için 0,4 , içeri geçen ses düzeyi için 0,4 ve NBD maliyeti için 0,2 alınmıştır.

\section{Adım Ideal ve Negatif ideal Çözüm}

Burada ağırlıklı matriste her bir kolonda maksimum ve minimum değerler tespit edilir. ${ }^{27}$

$$
A^{*}=\left\{\left(\max _{i} v_{i j} \mid j \in J\right),\left(\min _{i} v_{i j} \mid j \in J^{\prime}\right\}\right.
$$

$$
A^{*}=\left\{\underset{i}{(m a x} v_{i j} \text { olm ak üzere }\right\}
$$

$\Rightarrow A^{*}=\left\{\mathbf{v}_{1}^{*}, \mathbf{v}_{2}^{*}, \ldots, v_{n}^{*}\right\}$ her bir sü tu na ait m aksim um değerler,

$$
\begin{aligned}
A^{-}=\left\{\left(\min _{i} v_{i j} \mid j \in J\right),\left(\max _{i} v_{i j} \mid j \in J^{\prime}\right\}\right. \\
\mathbf{A}^{-}=\left\{\left(\min _{\mathbf{i}} \mathbf{v}_{\mathbf{i j}} \text { olm ak üzere }\right\}\right.
\end{aligned}
$$

$\Rightarrow A^{-}=\left\{v_{1}^{-}, v_{2}^{-}, \ldots, v_{n}^{-}\right\}$h er bir sü tu na ait m inim um değerlerdir .

\footnotetext{
${ }^{27} \mathrm{http}: / /$ www.deu.edu.tr/userweb/k.yaralioglu/dosyalar/TOPSIS_Yontemi. doc, 2019.
} 
Tablo 8. İdeal ve Negatif İdeal Çözüm

\begin{tabular}{lccc}
\hline & Isı kaybı (kWh) & i̇çeri geçen ses düzeyi (dbA) & NBD maliyeti (TL) \\
\hline İdeal Çözüm Değerleri (A*) (maksimum değerler) & 0,2183 & 0,1892 & 0,1359 \\
İdeal Olmayan Çözüm Değerleri (A-) (minimum değerler) & 0,1367 & 0,175 & 0,072 \\
\hline
\end{tabular}

Tablo 9. Ayrım Ölçümleri

\begin{tabular}{|c|c|c|c|c|}
\hline \multirow[t]{2}{*}{ Alternatifler } & \multicolumn{3}{|c|}{ Kriterler } & \multirow[t]{2}{*}{$S_{i}^{*}$} \\
\hline & Isı kaybı (kW) & İçeri geçen ses düzeyi (dbA) & NBD maliyeti (TL) & \\
\hline Hibrid duvar & 0,13856588 & 0,179746 & 0,072390377 & 0,102373693 \\
\hline Tuğla duvar & 0,19502064 & 0,175016 & 0,072364621 & 0,069136477 \\
\hline Giydirme cam & 0,21831505 & 0,189207 & 0,135933334 & 0 \\
\hline Taş kaplama duvar & 0,19081841 & 0,175016 & 0,075119442 & 0,068195993 \\
\hline Gaz beton duvar & 0,13672352 & 0,175016 & 0,073499612 & 0,103680806 \\
\hline
\end{tabular}

Tablo 10. Ayrım Ölçümleri

\begin{tabular}{|c|c|c|c|c|}
\hline \multirow[t]{2}{*}{ Alternatifler } & \multicolumn{3}{|c|}{ Kriterler } & \multirow[t]{2}{*}{$S_{i}^{*}$} \\
\hline & Isı kaybı (kW) & İçeri geçen ses düzeyi (dbA) & NBD maliyeti (TL) & \\
\hline Hibrid duvar & 0,13856588 & 0,179746 & 0,072390377 & 0,00540966 \\
\hline Tuğla duvar & 0,19502064 & 0,175016 & 0,072364621 & 0,059021764 \\
\hline Giydirme cam & 0,21831505 & 0,189207 & 0,135933334 & 0,10519064 \\
\hline Taş kaplama duvar & 0,19081841 & 0,175016 & 0,075119442 & 0,054907094 \\
\hline Gaz beton duvar & 0,13672352 & 0,175016 & 0,073499612 & 0,001665107 \\
\hline
\end{tabular}

Her iki formülde de fayda (maksimizasyon), ise kayıp (minimizasyon) değerini göstermektedir.

Yukarıda bahsedilen formülasyona göre belirlenen "Ideal ve Negatif İdeal Çözüm" sonuçları Tablo 8'de görülmektedir.

\section{Adım Ayrım Ölçümleri}

TOPSIS yönteminde her bir karar noktasına ilişkin değerlendirme faktör değerinin İdeal ve negatif ideal çözüm setinden sapmalarının bulunabilmesi için Euclidian Uzaklık Yaklaşımından yararlanılmaktadır. ${ }^{27}$

$$
S_{i}^{*}=\sqrt{\sum_{j=1}^{n}\left(v_{i j}-v_{j}^{*}\right)^{2}}
$$

Si İdeal Ayrım ölçümünü, $V_{i j}$ ideal çözüm setindeki maksimum değeri ve $v_{\text {i }}$ ise ağırlıklı karar matrisindeki karar noktaları değerlerini ifade etmektedir.

$$
S_{i}^{-}=\sqrt{\sum_{j=1}^{n}\left(v_{i j}-v_{j}^{-}\right)^{2}}
$$

${ }^{27}$ http://www.deu.edu.tr/userweb/k.yaralioglu/dosyalar/TOPSIS_Yontemi. doc, 2019.
Tablo 11. İdeal Çözüme Göreli Yakınlık $\left(C_{i}^{*}\right)$

\begin{tabular}{lc} 
Alternatifler & $\boldsymbol{C}_{\boldsymbol{i}}^{*}$ \\
\hline Hibrid duvar & 0,05019013 \\
Tuğla duvar & 0,46053819 \\
Giydirme cam & 1 \\
Taş kaplama duvar & 0,44602532 \\
Gaz beton duvar & 0,01580609 \\
\hline
\end{tabular}

$\mathrm{Si}^{-}$Negatif İdeal Ayrım ölçümünü, $\mathrm{V}_{\mathrm{ij}}$ negatif ideal çözüm setindeki minimum değeri ve $v_{j}$ ise ağırlıklı karar matrisindeki karar noktaları değerlerini ifade etmektedir.

Herbir duvar alternatifi için yukarıdaki formülasyona göre belirlenen "Ideal ve Negatif İdeal Ayrım Ölçümleri" Tablo 9 ve 10'da yer almaktadır.

\section{Adım Ideal Çözüme Göreli Yakınlık (Ci*)}

Her bir karar noktasının ideal çözüme göreli yakınlığının $\left(C_{i}^{*}\right)$ hesaplanmasında ideal ve negatif ideal ayırım ölçülerinden yararlanılır. ${ }^{27}$ 


$$
C_{i}^{*}=\frac{S_{i}^{-}}{S_{i}^{-}+S_{i}^{*}}
$$

Burada $C_{i}^{*}$ değeri $0 \leq C_{i}^{*} \leq 1$ aralığında değer alır ve $C_{i}^{*}=1$ ilgili karar noktasının ideal çözüme, $C_{i}^{*}=0$ ilgili karar noktasının negatif ideal çözüme mutlak yakınlığını gösterir. Ele alınan duvar alternatifleri için elde edilen "ideal Çözüme Göreli Yakınlık" değerleri Tablo 11'de görülmektedir.

$A_{3}, A_{2}, A_{4}, A_{1}, A_{5}$ şeklinde elde edilen sıralamadan anlaşılacağı üzere 2. DG. Bölgesi'nden İstanbul için en uygun kesit seçeneğini bu örnekler arasında gaz beton duvar alternatifi vermektedir. Ardından olumludan olumsuza sırasıyla gaz beton, hibrid duvar, taş kaplama tuğla duvar, tuğla duvar ve cam giydirme cephe alternatifleri sunmaktadır. Ancak tablodan da görüleceği gibi Gaz beton kesit ile hibrid duvar birbirine çok yakın değerleri oluşturmaktadır.

\section{Değerlendirme}

Çalışma kapsamında İstanbul'da 5 farklı yapı kabuğu kesiti için yapılan ISI, ses ve maliyet parametrelerine ilişkin karşılaştırma sonuçlarında sırasıyla gaz beton duvar ile radyant hibrid duvar TOPSis ile en iyi koşulları vermektedir. Böylelikle yapı kabuğu Isı kaybı parametresi hesaplarında gaz beton duvar ile hibrid duvarın birbirine çok yakın performans göstermesi ve diğer alternatif duvar kesitlerine göre daha düşük değerler elde etmesi ile bina avantajlı hale geçmektedir. İçeri geçen ses düzeyinde ve maliyetlerde ise diğer duvar kesitlerine göre minimum fark meydana gelmesi ile söz konusu durum korunmaktadır.

Mevcut ve geleneksel sistemler ile temiz enerji tüketimine alternatif olarak değerlendirilebilecek "radyant hibrid duvar sistemi" karşılaştırıldığında elde edilen sonuçlar bazı örneklerde birbirine oldukça yakın ve iyi sonuçlar vermektedir. İstanbul ili için Isı-ses-maliyet parametrelerine verilen ağırlık kriter derecelerine göre gaz beton duvar ve radyant hibrid duvar örneklerinin birbirine eş sayılacak yakınlıkta sonuçlar vermesi, iklim bölgesi özelinde değerlendirilebilir. Ilıman nemli iklim bölgesinden İstanbul il örneğinde yapılan analizlerde seçilen bu iki duvar örneğinin, birbirine çok yakın $U$ değerine sahip kesitlerde olması ISI kayıp sonuçlarını da pozitif yönde etkilemektedir. Ancak farklı iklim bölgelerinde diğer parametreler açısından ve çalışmada kullanılacak olan farklı ağılık kriter değerleri ile diğer kesitlerin de farklı performanslar gösterecekleri öngörülmektedir.

\section{Sonuç}

Çalışmada, kabuk performans kriterlerini belirlemede büyük etkiye sahip ısı kaybı, içeri geçen ses düzeyi ve maliyet hesaplamaları gerçekleştirilmiştir. Bu kriterlerin özellikle yeni geliştirilmekte olan "yüzeyden ısıtma-soğutma sistemli modüler hibrid duvar" elemanı açısından olduğu kadar, geleneksel ve mevcut teknolojili kabuk sistemleri açısından da kritik rol oynadığı bilinmektedir.

Farklı yapı elemanları ile oluşturulacak kabuk sistemlerinin geliştirilmesine olanak vermesi açısından ele alınan kriterler değiştirilerek arttılıbilir. Bu yüzden kriterlerin ekolojik ve ekonomik faktörler öncelikli kabul edilerek çeşitlendirilmesi, farklı yapı elemanlarından oluşan tasarımların artmasını sağlayacaktır. Bu makalede bir örneği sunulan yenilikçi tasarımların kurgulanmasında dikkat edilecek kriterler;

- Attk oluşturmayan / Minimum atık oluşturan yapı elemanları seçimi,

- Geri dönüşüme uygun malzemeler,

- Yüksek işçilik ve maliyet kaybını azaltan ekonomik tasarımlar,

- Farklı malzeme birlikteliklerine uyumlu eleman seçi$\mathrm{mi}$,

- Birleşim noktalarının hatasız olması,

- Bina HVAC sistem türlerinin hem yapı elemanı hem de çevre açısından temiz enerjili olarak belirlenmesi,

- Uygulama öncesi simülasyonlar ile analiz edilerek, kontrol mekanizmalarının geliştirilmesi,

olarak sıralanabilir.

Dünya genelinde artan temiz ve yenilenebilir enerji kaynaklarına ilişkin talep, mevcut yapı sistem çözümleri ile sürdürülebilir olma halinden çıkmaktadır. Bu yüzden geleceğin bina kabuk sistemleri hem ilk yatırım hem enerji hem de tüketim (yakıt, elektrik vb.) maliyetleri açısından daha avantajlı ve çevre açısından da minimum zararlı halde olmalıdırlar.

\section{Kaynaklar}

"2019 Yilı İņ̧aat ve Tesisat Birim Fiyatları", (2019) T.C. Çevre ve Şehircilik Bakanlığı Yüksek Fen Kurulu Başkanlğı.

"Binaların Gürültüye Karşı Korunması Hakkında Yönetmelik", (2017) T.C. Çevre ve Şehircilik Bakanlığı, T.C. Resmi Gazete, Sayı 30082.

"İstanbul İmar Yönetmeliği", (2008) İstanbul Büyükşehir Belediyesi, Sayı 30426.

Building class definitions. [Online]. Available: https://www. boma.org/BOMA/Research-Resources/Industry_Resources/ Building_Class_Definitions/[Erişim tarihi 29 Temmuz 2019]

Design Builder Software, (2006) DesignBuilder 1.2 User Manual. Eldem, N. (1950) "Idari ve Ticari Büro Binaları", İstanbul, iTü.

EN 1793-3. Anon. Road traffic noise reducing devices-test method for determining the acoustic performance-Part 3: Normalized traffic noise spectrum, Brussels, September 1997.

Gedik, G. Z. (2001) "Hazır Dış Duvar Elemanlarının Isısal Konfor Açısından İncelenmesi ve Değerlendirilmesi", Yalıtım 2001 Kongresi, 23-25 Mart 2001, TMMOB Makine Mühendisleri Odası Eskişehir, s. 56-67.

Gedik, G. Z., Atayılmaz, Ş. Ö., Erikci, S. N., Çetin, M. G., Topaçoğlu, Y., Koca, A. I., Gemici, Z. (2016) "Yüzeyden Isıtma Soğutma 
Sistemli Modüler Hibrit Duvar Yapısının Geliştirilmesi", 0462. STZ.2013-2 no'lu SAN-TEZ Projesi.

Gedik, G. Z., Atayılmaz, Ş. Ö., Erikci, S. N., Çetin, M. G., Topaçoğlu, Y., Koca, A. İ., Gemici, Z. (2016) "Yüzeyden Isıtma Soğutma Sistemli Modüler Hibrit Duvar Yapısının Geliştirilmesi", 0462. STZ.2013-2 no'lu SAN-TEZ Projesi, 1. Dönem toplant raporu, Ekim 2014.

Gemici, Z. (2017) "Experimental Examination of Thermal Comfort Performance of a Radiant Wall Panel System: Comparison Between Different Heating Wall Configurations", Journal of Thermal Science and Technology, Sayı 37, No 1, s. 69-78.

Göçer, C. ve Işık, B. (2007) "Beton Esaslı Prefabrike Ilköğretim Binalarında Dış Duvar Özellikleri-Çevre iliş̧kisi”, itüdergisi/a, Sayı 6, No.1, s. 55-65.

Gür, N.V. ve Aygün, M. (2008) “Mimaride Sürdürülebilirlik Kapsamında Değişken Yapı Kabukları için Bir Tasarım Destek Sistemi”, itüdergisi/a, Sayı 7, No 1, s. 74-82.

http://www.deu.edu.tr/userweb/k.yaralioglu/dosyalar/TOPSIS_ Yontemi.doc [Erişim tarihi 3 Eylül 2019].

http://www.fizibilite.info/net-bugunku-deger/ [Erişim tarihi 19 Şubat 2019].

https://www.epdk.org.tr/Detay/Icerik/3-0-1/tarifeler [Erişim tarihi 1 Mart 2019].

https://www.igdas.istanbul/perakende-satis/ [Erişim tarihi 1 Mart 2019].

https://www.tcmb.gov.tr/wps/wcm/connect/tr/tcmb+tr/ main +menu/temel+faaliyetler/para+politikasi/ merkez+bankasi+faiz+oranlari [Erişim tarihi 1 Mart 2019]

https://www.youtube.com/watch?v=S2zBO7CBweg [Erişim tarihi 20 Ekim 2019].
Karslı, H. (2008) “Sürdürülebilir Mimarlık Çerçevesinde Ofis Yapılarının Değerlendirilmesi ve Çevresel Performans Analizi için Bir Model Önerisi", Sanatta Yeterlilik Tezi, Mimar Sinan Güzel Sanatlar Üniversitesi İç Mimarlık Anasanat Dalı.

Koca, A., Açıkgöz Ö., Çebi, A., Çetin, G., Dalkılıç, A. S., Wongwises, S. (2018) “An Experimental Investigation Devoted to Determine Heat Transfer Characteristics in a Radiant Ceiling Heating System", Heat Mass Transfer, Sayı 54, s. 363-375.

Koca, A., Gemici, Z., Topacoglu, Y., Cetin, M. G., Acet, R. C., Kanbur, B. B. (2014) "Experimental Investigation of Heat Transfer Coefficients Between Hydronic Radiant Heated Wall and Room", Energy and Buildings, Sayı 82, s. 211-221.

Lollini M., Barozzi, B., Fasano, M., Meroni, G., Zinzi, M. (2006) "Optimisation of Opaque Components of the Building Envelope. Energy, Economic and Envronmental Issues", Building and Environment, Sayı 41, No 8, s. 1001-1013.

Özel, M. (2003) “Duvar Yüzeylerinde Periyodik Sıcaklık Değişimi Olan Binalarda Isı Kazanç ve Kayıplarını Minimum Yapacak Yöntemlerin Araştırılması", Doktora Tezi, Fırat Üniversitesi, Fen Bilimleri Enstitüsü.

Sicola, M. (2017) “Commercial Real Estate Terms and Definitions", NAIOP Research Foundation, s. 30-31.

Tye-Gingras, M. ve Gosselin, L. (2012) "Comfort and Energy Consumption of Hydronic Heating Radiant Ceiling and Walls Based on CFD Analysis", Building and Environment, Sayı 54, s. 1-13.

Zhang X, Li, N., Su, L., Sun, Y., Qian, J. (2016) “Experimental Study on the Characteristics of Non-steady Radiation Heat Transfer in the Room With Concrete Ceiling Radiant Cooling Panels", Building and Environment, Sayı 96, s. 157-169. 